\title{
Preparation and characteristics of yogurt added with enzymatically saccharified Korean rice wine lees powder
}

\author{
Dong Chung Kim ${ }^{1} \cdot$ Sun Im Won ${ }^{2} \cdot$ Man-Jin $\operatorname{In}^{2}$ \\ 효소로 당화시킨 주박 분해물을 첨가한 요구르트의 발효 특성
}

김동청 ${ }^{1} \cdot$ 원선임 ${ }^{2} \cdot$ 인만진 $^{2}$

Received: 21 August 2018 / Accepted: 2 October 2018 / Published Online: 31 December 2018

(C) The Korean Society for Applied Biological Chemistry 2018

\begin{abstract}
This study was carried out to determine the effect of enzymatically saccharified Korean rice wine lees powder (eKRWLP) on the quality characteristics and storage stability of curd yogurt. Yogurt with different contents $[0.5-2.0 \%(\mathrm{w} / \mathrm{w})]$ of eKRWLP was incubated with commercially available mixed lactic acid bacteria (Lactobacillus acidophilus, Streptococcus thermophilus, Bifidobacterium longum) at $40{ }^{\circ} \mathrm{C}$ for $18 \mathrm{~h}$. The production of acid measured at $\mathrm{pH}$ and titratable acidity of yogurts increased with increasing eKRWLP content. After $12 \mathrm{~h}$ fermentation, titratable acidity of eKRWLP yogurt was $0.77-0.90 \%$ and was higher than that $(0.72 \%)$ of yogurt made without eKRWLP. The viable cell counts of lactic acid bacteria in eKRWLP yogurts were increased in proportion to the addition of eKRWLP, and increased up to 8.01$8.13 \log \mathrm{CFU} / \mathrm{g}$ after $12 \mathrm{~h}$ incubation. The repressive effect of whey separation in eKRWLP yogurt curd significantly decreased than that in Korean rice wine lees powder (KRWLP) yogurt. With sensory evaluation, yogurt with $0.5 \%$ eKRWLP obtained the highest scores among all eKRWLP yogurts. When eKRWLP yogurts and the control preparations fermented for $12 \mathrm{~h}$ were incubated at $4{ }^{\circ} \mathrm{C}$, their $\mathrm{pHs}$ and titratable acidities were slightly

Man-Jin In $(\bowtie)$

E-mail: manjin@chungwoon.ac.kr

${ }^{1}$ Department of Chemical Engineering, Chungwoon University, Incheon 22100, Republic of Korea

${ }^{2}$ Department of Human Nutrition and Food Science, Chungwoon University, Hongseong 32244, Republic of Korea

This is an Open Access article distributed under the terms of the Creative Commons Attribution Non-Commercial License (http://creativecommons. org/licenses/by-nc/3.0/) which permits unrestricted non-commercial use, distribution, and reproduction in any medium, provided the original work is properly cited.
\end{abstract}

changed and the number of viable lactic acid bacteria were well maintained above $10^{7} \mathrm{CFU} / \mathrm{g}$ for 16 days.

Keywords Fermentation characteristics - Saccharified Korean rice wine lees powder $\cdot$ Storage stability $\cdot$ Yogurt

\section{서 론}

약주, 청주 등의 양조 과정에서 알코올 발효 후 발효액을 압착 하여 술을 얻고 남는 부산물인 주박은 원료인 쌀의 약 $20 \%$ 정 도로 얻어진다. 최근에는 한류의 일환으로 막걸리와 같은 전통 주의 생산과 소비가 증가하고, 지역의 고유의 전통주 복원과 상 품화가 활발해짐에 따라 그 부산물인 주박의 양도 따라서 증가 하고 있다. 현실적으로 주박은 수분함량이 높아 저장성이 낮으 므로 대부분은 폐기되며, 일부가 야채 절임류와 식초의 제조와 동물사료, 비료 등에 사용되는 실정이다[1]. 그러나 주박은 알 코올 발효에 사용되지 못한 탄수화물과 단백질이 주성분이므로 식량이 부족했던 시기에는 대체식품으로 이용했을 정도로 영양 적으로도 우수하며, 양조과정에서 생성된 유기산, 비타민, 알코 올, 효소와 효모 등을 함유하고 있다[2]. 특히 다량의 효소가 포 함되어 소화, 흡수를 촉진시킬 뿐 만 아니라, 식후 혈당 조절 [3], 항산화[4], 항알러지[5], tyrosinase와 ACE 저해[6], 항염증 [7], 면역 활성화[8] 등의 생리활성 성분이 있는 것으로 보고되 어 있다. 그러므로 주박 분말 혹은 주박 추출물을 모닝롤[9], 야 콘 장아찌[10], 설기떡[11], 증편[12], 프랑크푸르트 소시지[13], 머핀[14], 쿠키[15] 등의 식품에 첨가하여 식품의 품질을 개선 하고 주박의 생리활성을 이용하는 연구가 꾸준하게 진행되고 있 다. 또한 주박을 미생물 배양과 발효식품에 활용하는 연구는 효 모 포자 생산[16], probiotic bacteria 생육배지[17], 식초[18] 및 
요구르트[19] 등이 보고되어 있는 정도이다. 특히 요구르트 제 조에서 주박 분말의 첨가는 젖산균의 생육과 산의 생성을 촉진 하며 발효 후 요구르트에서 유청의 분리를 억제하여 커드의 안 정성을 향상시키는 효과가 있는 것으로 보고되었다[19].

따라서 본 연구에서는 활용이 제한되고 있으나 다양한 생리 활성이 보고된 주박을 식품소재로 활용하는 연구의 계속으로 효 소로 당화시킨 주박 분말을 첨가한 요구르트를 제조하였다. 젖 산균의 발효특성과 관능적 특성, 발효물의 저장 안정성을 조사 하였으며, 특히 주박 당화물이 젖산균의 생육에 미치는 효과와 요구르트 발효액에서 유청의 분리를 억제하는 효과를 분석하여 주박 당화물을 식품 소재와 유산균 배양용 배지로 이용하기 위 한 기본적인 자료를 확보하고자 하였다.

\section{재료 및 방법}

\section{재료}

결성양조장(홍성, 대한민국)의 쌀 막걸리 발효 원액을 원심분리 $\left(1,000 \times g, 4{ }^{\circ} \mathrm{C}, 15\right.$ 분 $)$ 하여 상등액을 제거한 후 침전물을 동결 건조로 주박 분말을 준비하였으며, 탈지분유는 서울우유협동조 합의 제품을 구입하였다. 요구르트 제조의 starter는 Lactobacillus acidophilus, Streptococcus thermophilus, Bifidobacterium longum 혼합 유산균 제품인 ABT-B Yogurt Culture (Danisco USA Inc., Madison, WI, USA)를 별도의 배양 없이 사용하였다.

\section{주박 효소 당화물의 제조 및 요구르트 배양}

동결 건조한 주박 분말 $20 \%$ 현탁액을 $80{ }^{\circ} \mathrm{C}$ 에서 10 분간 열처 리하고 $\alpha$-amylase와 glucoamylase (Sigma Chem., St. Louis, $\mathrm{MO}, \mathrm{USA})$ 을 순차적으로 처리하여 주박에 함유된 전분을 당화 시킨 후 동결 건조하여 주박 효소 당화물을 제조하였다[20]. 주 박 효소 당화물을 함유한 요구르트는 탈지분유 $10 \%$ 현탁액에 주박 효소 당화물을 $0.5-2.0 \%$ 첨가하고 $100{ }^{\circ} \mathrm{C}$ 에서 10 분간 열 처리한 다음 실온으로 냉각시킨 후 starter를 $0.02 \%$ 첨가하고 $40{ }^{\circ} \mathrm{C}$ 에서 정치배양하여 제조하였다.

\section{$\mathrm{pH}$ 와 적정산도}

요구르트 발효액의 $\mathrm{pH}$ 는 $\mathrm{pH}$ meter (model 915DC, Istek, Seoul, Korea)를 이용하여 직접 측정하였다. 적정산도는 요구르 트를 멸균 식염수로 10 배 희석한 후 phenolphthalein을 지시약으 로 하여 $0.01 \mathrm{~N} \mathrm{NaOH}$ 로 적정하고 젖산 함량으로 환산하였다.

\section{환원당}

요구르트 발효액의 환원당 함량은 포도당을 표준물질로 하여 DNS (3,5-dinitrosalicylic acid)법으로 분석하였다.

\section{젖산균수}

요구르트 발효액 $1 \mathrm{~g}$ 을 멸균 생리식염수에 단계적으로 희석한 후 젖산균 배양용 배지(Lactobacillus MRS agar, Difco Laboratories, Detroit, MI, USA)에 $1 \mathrm{~mL}$ 씩 pour plate method 로 혼합하고 $37^{\circ} \mathrm{C}$ 에서 24-36시간 배양하여 형성된 colony를 계 측하였으며, 젖산균 생균수는 시료 $\mathrm{g}$ 당 colony forming units $(\mathrm{CFU} / \mathrm{g})$ 로 나타내었다.

\section{커드 안정성}

커드 안정성은 요구르트 발효액에서 원심분리 후 커드에서 유 청의 분리정도를 측정하는 것으로 다음과 같이 조사하였다[19]. 눈금이 있는 원심분리관에 혼합시킨 발효액 $10 \mathrm{~mL}$ 를 넣고 원 심분리 $\left(500 \times g, 4{ }^{\circ} \mathrm{C}, 5\right.$ 분 $)$ 한 후 상등액과 침전물의 부피를 측정 하였다. 유청 비율(whey ratio)은 전체부피에 대한 상등액 부피 의 비로 게산하였다.

\section{관능검사와 통계분석}

관능검사는 12 시간 발효시킨 요구르트에 $5 \%$ 로 설탕을 가하고 $4{ }^{\circ} \mathrm{C}$ 에서 24 시간 보관 후 청운대학교 식품영양학과 대학생 20 명에게 색, 향, 맛, 점도, 종합적인 기호도에 대하여 5점 척도법 [아주 싫다(1점), 보통이다(3점), 아주 좋다(5점)]으로 실시하였다 [21]. 관능검사 결과는 SPSS Statistics (Statistical Package for Social Science, SPSS Inc., Chicago, IL, USA, version 23.0) 를 이용하여 통계처리 하였으며 ANOVA로 $5 \%$ 수준에서 각 시 료간의 유의적인 차이를 Duncan's multiple range test로 검증하 였다(유의수준 $p<0.05$ ).

\section{저장성}

요구르트의 저장성은 12 시간 발효시킨 요구르트를 $4{ }^{\circ} \mathrm{C}$ 에서 16 일간 보관하면서 $\mathrm{pH}$, 적정산도, 젖산균수의 변화를 경시적으로 조사하였다.

\section{결과 및 고찰}

\section{주박 효소 당화물}

막걸리 주박 분말의 조단백질과 총탄수화물은 각각 9.76와 $79.40 \%$ 로 탄수화물이 대부분이며, 환원당은 $3.20 \%$ 로 미생물이 쉽게 이용할 수 있는 발효성 당의 함량이 낮다는 기존의 연구 결과[19]를 바탕으로 요구르트 발효에서 주박에 함유된 당의 활 용도를 향상시키기 위하여 액화 및 당화효소를 처리하여 주박 효소 당화물을 제조하였다. 효소 처리 후 동결건조한 주박 당 화물의 환원당 함량은 $73.0 \%$ 로 효소처리 전과 비교하면 주박 에 함유된 탄수화물의 대부분이 환원력을 보이는 저분자 당류 로 분해된 것으로 판단된다.

\section{pH와 적정산도의 변화}

탈지분유 $10 \%(\mathrm{w} / \mathrm{w})$ 에 주박 당화물 분말을 0 (대조군), 0.5 , $1.0,2.0 \%$ 첨가한 현탁액을 $40{ }^{\circ} \mathrm{C}$ 에서 18 시간 동안 정치배양으 로 요구르트를 제조하면서 $\mathrm{pH}$ 와 적정산도의 변화를 경시적으 로 측정하였다. 모든 실험군에서 요구르트의 $\mathrm{pH}$ 는 발효 9시간 까지 급격하게 감소하였고, 그 이후 발효 18 시간까지는 완만하 게 감소하였다(Fig. 1A). 발효 12시간 후 대조군의 $\mathrm{pH}$ 는 4.43 이며, 주박 당화물 요구르트의 $\mathrm{pH}$ 는 4.36 ( $0.5 \%$ 첨가), 4.30 (1.0\% 첨가), 4.23 (2.0\% 첨가)로 주박 당화물 분말을 첨가한 조건에서 더 낮은 $\mathrm{pH}$ 를 나타냈으며, $\mathrm{pH}$ 감소 정도는 주박 당 화물 분말의 첨가량에 비례하였다. 이러한 $\mathrm{pH}$ 의 감소는 쌀 분 말을 2-6\% 첨가한 요구르트[22]와 주박 분말을 $0.5-2.0 \%$ 첨가 한 요구르트[19]에서도 동일하게 보고되었다. 발효 18시간에 주 박 당화물 요구르트의 $\mathrm{pH}$ 는 4.14-4.22로 측정되어 요구르트는 

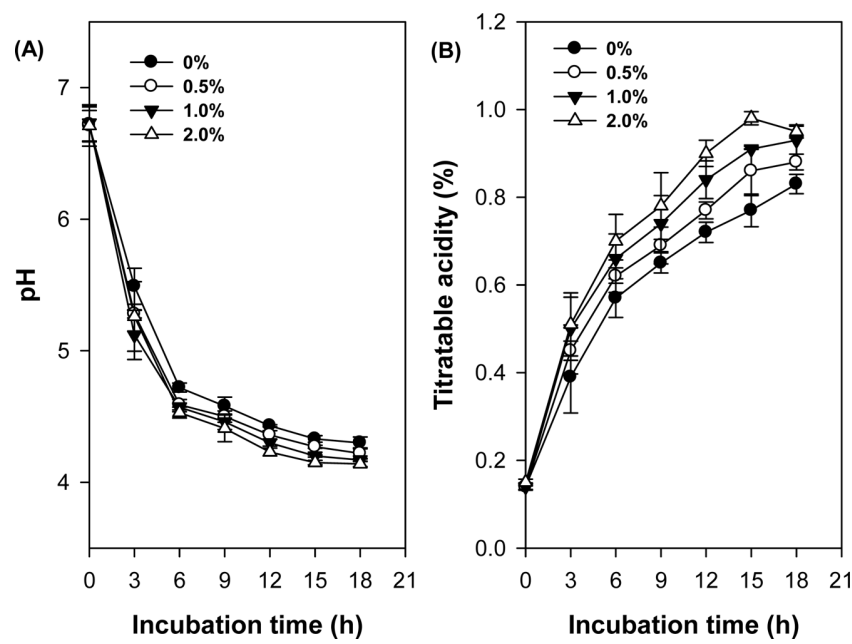

Fig. 1 Change in $\mathrm{pH}$ (panel A) and titratable acidity (panel B) of yogurt added with enzymatically saccharified Korean rice wine lees powder during fermentation at $40{ }^{\circ} \mathrm{C}$ for $18 \mathrm{~h}$

$\mathrm{pH} 3.27-4.53$ 이 바람직하다는 기존의 보고[23]에 부합되었다. 이 는 쌀 분말을 $2-6 \%$ 첨가한 요구르트에서 발효 14 시간에 $\mathrm{pH}$ 4.32-4.35를 나타낸 결과[22]보다 다소 낮았으나 주박 분말을 $0.5-2.0 \%$ 첨가한 경우 발효 12 시간에 $\mathrm{pH}$ 4.24-4.32인 결과[19] 와는 매우 유사하였다. 발효 중 적정산도는 모든 실험군에서 발 효 12시간까지 급격하게 증가하였으며(Fig. 1B), 증가 정도는 $\mathrm{pH}$ 의 변화와 일치하는 경향이었다. 발효 12 시간 후 대조군의 적정산도는 $0.72 \%$, 주박 당화물 요구르트의 적정산도는 $0.77 \%$ (0.5\% 첨가), $0.84 \%$ ( $1.0 \%$ 첨가), $0.90 \%$ ( $2.0 \%$ 첨가)로 산의 생성이 주박 당화물 첨가량에 비례하여 촉진되는 것으로 나타 났다. 이는 주박 분말을 첨가한 요구르트[19]와 일치하는 경향 으로 주박 당화물의 첨가로 원료 중 환원당 함량이 $0.37-1.46 \%$ 증가되었으나 요구르트 발효과정에서 주박 당화물이 산의 생성 에 미치는 영향은 주박과 매우 유사한 것으로 판단된다. 따라 서 곡류를 첨가한 요구르트에서 곡류에 함유된 발효촉진물질이 산 생성을 촉진한다는 보고[24]를 참고하면 본 연구에서도 주 박을 첨가한 결과[19]와 동일하게 산의 생성 촉진은 미량으로 작용하는 발효촉진물질에 기인하는 것으로 사료되었다.

\section{환원당과 젓산균 수의 변화}

탈지분유에 주박 당화물 분말을 첨가하여 제조한 요구르트의 환 원당 함량의 변화를 조사하였다. 그 결과(Fig. $2 \mathrm{~A})$, 발효 전 환 원당 함량은 주박 당화물의 첨가로 $4.21 \%$ (대조군)에서 $4.68 \%$ (0.5\% 첨가), $5.23 \%$ ( $1.0 \%$ 첨가), $5.96 \%$ ( $2.0 \%$ 첨가)로 증가 하였다. 발효 12 시간 후 환원당 함량은 $3.70 \%$ (대조군), $3.86 \%$ (0.5\% 첨가), $4.03 \%$ ( $1.0 \%$ 첨가), $4.77 \%$ ( $2.0 \%$ 첨가)로 감소 하였으며, 주박 당화물의 첨가량이 증가할수록 발효 12 시간 동 안 환원당의 소비가 $0.51 \%$ (대조군)에서 $1.19 \%$ ( $2.0 \%$ 첨가)로 증가하였다. 환원당은 발효과정에서 젖산균의 영양원으로 이용 되면서 유기산, 알코올, 이산화탄소 등의 물질로 변환되어 감소 하므로 본 연구에서도 환원당의 감소가 적정산도의 증가(Fig. $1 \mathrm{~B})$ 에 기여한 것으로 사료되었다. 동시에 주박 당화물 분말의 첨가량에 따른 젖산균 생균수의 변화를 조사하였다(Fig. 2B). 발
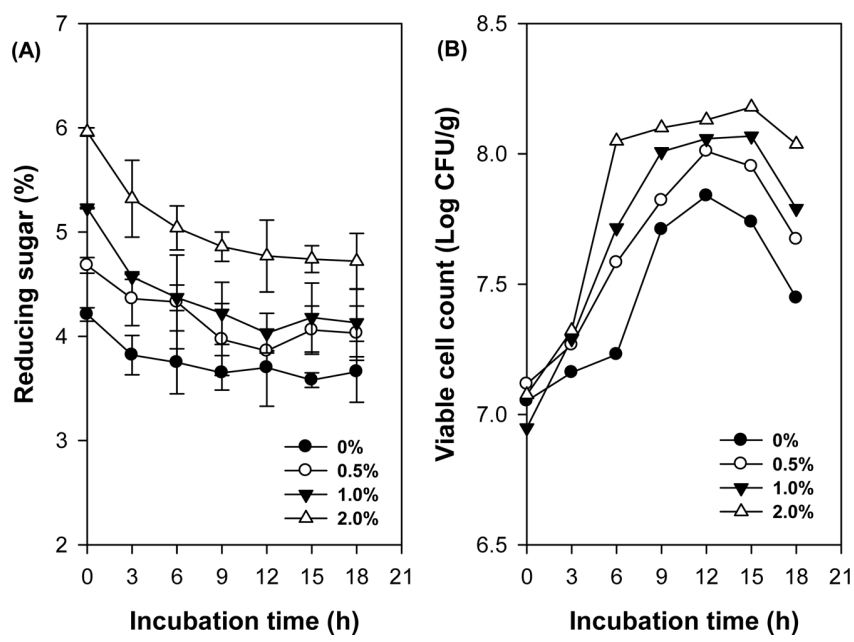

Fig. 2 Change in reducing sugar contents (panel A) and lactic acid bacteria counts (panel B) of yogurt added with enzymatically saccharified Korean rice wine lees powder during fermentation at $40{ }^{\circ} \mathrm{C}$ for $18 \mathrm{~h}$

효 전 젖산균 수는 모든 실험군에서 6.95-7.12 $\log \mathrm{CFU} / \mathrm{g}$ 으로 유 사하였으나, 발효 3-9시간에 균이 빠르게 성장하여 발효 12시 간 후 젖산균 수는 $7.83 \log \mathrm{CFU} / \mathrm{g}$ (대조군), $8.01 \log \mathrm{CFU} /$ $\mathrm{g}(0.5 \%$ 첨가), $8.06 \log \mathrm{CFU} / \mathrm{g}(1.0 \%$ 첨가), $8.13 \log \mathrm{CFU} /$ $\mathrm{g}(2.0 \%$ 첨가)로 증가하였다. 젖산균의 최대 생균수 뿐만 아니 라 발효 초기(3-9시간)에 젖산균의 성장도 주박 당화물의 첨가 량에 비례하여 증가하였다. 젖산균의 생육에는 비타민, 아미노 산, 핵산 등의 복합영양소가 필요하므로 주박 당화물 분말이 이 러한 복합영양소의 공급원으로 작용하여 젖산균의 생육이 촉진 되어 산의 생성이 증가하는 것으로 판단되었다. 주박 당화물 분 말의 첨가량에 비례하여 젓산균 생균수가 증가하는 경향은 탈 지분유에 오디 분말을 $0.5-3.0 \%$ 혼합한 요구르트[25]와 주박 분 말을 $0.5-2.0 \%$ 첨가한 요구르트 [19]에서도 같은 경향이었다. 본 연구에서 발효 12 시간 후 주박 당화물 분말 첨가군의 젖산균 생균수는 8.01-8.13 $\log \mathrm{CFU} / \mathrm{g}$ 로 현재 우리나라 축산물 성분규 격상 농후발효유의 총 젖산균 수 기준치인 $8.0 \mathrm{log} \mathrm{CFU} / \mathrm{g}$ 이 상에 부합되었다. 따라서 탈지분유에 주박 당화물 분말의 첨가 는 주박 분말과 동일하게 젖산균의 생육과 산 생성을 촉진시는 효과를 기대할 수 있을 것으로 여겨진다. 또한 산업적으로는 주 박을 효모[16]와 probiotic bacteria[17] 생육배지로 활용하는 연 구를 고려하면 주박 당화물은 비타민, 아미노산, 핵산 등의 복 합영양소뿐만 아니라 환원당 함량이 높기 $(73 \%)$ 때문에 probiotics를 포함한 다양한 미생물의 배양에 좀더 효과적인 배 지로 이용될 수 있을 것이다.

\section{커드 안정성}

요구르트에서 젖산균 발효로 생성되는 커드는 부드럽고 매끄러 운 조직감과 점성을 가지고 있으며 유청 분리는 요구르트의 품 질을 저하시키는 원인이다. 따라서 주박 당화물 분말을 첨가한 요구르트에서 생성된 커드의 안정성을 유청 분리 정도로 측정 하여 유청비율로 표시하였다. 탈지분유에 주박 당화물 분말을 첨가하고 12 시간 발효하여 제조한 요구르트의 유청 비율을 주 박 분말을 사용한 결과와 비교하였다(Fig. 3). 이때 주박 분말 


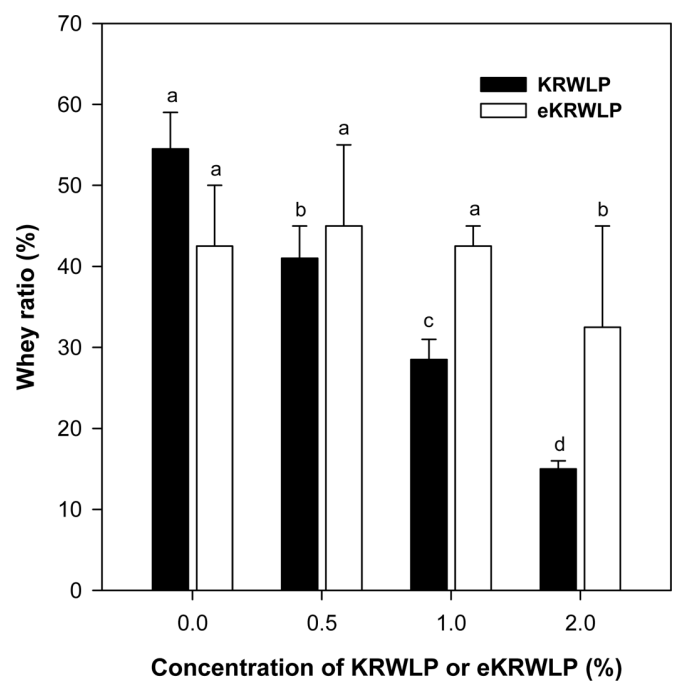

Fig. 3 Comparison for whey ratio of yogurts added with Korean rice wine lees powder (KRWLP) and enzymatically saccharified Korean rice wine lees powder (eKRWLP) after fermentation at $40^{\circ} \mathrm{C}$ for $12 \mathrm{~h}$. KRWLP data were taken from reference 19. Each bar represents the mean $\pm \mathrm{SD}$ of triplicates. Different letters are significantly different at $p<0.05$ among different KRWLP or eKRWLP concentration each group

의 유청 비율은 기존 결과[19]를 인용하였다. 주박 분말을 0.5$2.0 \%$ 첨가하면 첨가량에 비례하여 유청 분리를 억제하는 것으 로 보고되었다[19]. 한편, 주박 당화물을 첨가한 요구르트의 유 청 비율은 $42.5 \%$ (대조군), $45.0 \%$ ( $0.5 \%$ 첨가), $42.5 \%(1.0 \%$ 첨가), $32.5 \%$ ( $2.0 \%$ 첨가)로 조사되었다. 따라서 주박 당화물을 $0.5-1.0 \%$ 첨가한 조건에서는 유청 비율이 대조군과 매우 유사 하여 커드 안정성을 개선하는 효과가 나타나지 않았으며, $2.0 \%$ 로 첨가하는 요구르트에서만 유의하게 커드 안정성을 개선하는 효과가 관찰되었다. 주박 분말에 함유된 탄수화물의 대부분을 저분자 당류로 분해시킨 주박 당화물을 첨가하면 요구르트에서 유청 분리 억제 효과가 감소되는 것은 주로 주박에 함유된 비 발효성 탄수화물이 요구르트에서 커드의 안정화에 기여한다는 것을 의미한다. 요구르트 발효 중 우유 단백질이 gel을 형성하 는 과정에서 단백질 입자의 과도한 응집이 커드에서 유청이 분 리되는 원인[26]으로, 다당류를 함유한 다시마 열수 추출물[21] 을 첨가한 요구르트에서 커드의 침전억제 효과가 우수하였다는 보고도 이러한 판단의 근거가 되었다. 그러므로 요구르트 제조 과정에서 주박 당화물의 첨가는 주박 보다 유청 분리 억제 효
과가 미미한 것으로 조사되었다.

\section{관능특성}

탈지분유에 주박 당화물 분말을 첨가하여 $40{ }^{\circ} \mathrm{C}$ 에서 12 시간 발 효시킨 요구르트에 설탕 $5 \%$ 를 가한 후 $4{ }^{\circ} \mathrm{C}$ 에서 24 시간 보관 다음 색, 향, 맛, 점도 및 종합적인 기호도에 대한 관능평가를 실시하였다(Table 1). 점도를 제외한 항목에서 주박 당화물의 첨 가량에 따른 관능적인 평가 점수는 유의적으로 감소하였으며, 색, 맛, 향, 종합적인 기호도 항목에서 $0.5 \%$ 주박 당화물 분말 첨가 요구르트는 대조군과 유의한 차이를 나타내지 않았으며, $1.0 \%$ 이상을 첨가한 요구르트와는 대부분 유의적인 차이를 나 타내었다. 이러한 경향은 주박 분말을 본 연구와 동일한 농도 로 첨가한 요구르트는 모든 평가항목에서 관능적으로 차이가 없 었다는 결과[19]와는 상이한 것으로 주박 당화물에서 환원당 농 도 증가에 의한 반응성 향상에 기인하는 것으로 사료된다. 예 로써 주박 당화물의 농도에 비례하여 색에 대한 관능평가 점수 가 낮아지는 것은 환원당 증가로 갈변 반응 속도가 향상되므로 요구르트의 갈색화에 의한 것으로 판단된다. 주박 당화물의 높 은 환원당 함량 $(73 \%)$ 을 고려하면 요구르트 제조에서 자색 고구 마 효소분해물로 탈지분유을 부분적으로 대체하는 결과[27]와 동일하게 주박 당화물로 탈지분유의 일부를 대체하는 것이 효 과적일 것이다. 한편, 점도는 대조군과 모든 주박 당화물 첨가 군에서 유의미한 차이가 없었기에 점도의 변화가 주박 당화물 첨가 요구르트에서 기호도 감소에 미치는 영향은 미미한 것으 로 판단되었다. 그러므로 주박 당화물 분말을 요구르트에 첨가 하는 경우 관능적으로는 $0.5 \%$ 수준이 적당하며, 상품화를 위하 여는 감미료뿐만 아니라 추가로 첨가물을 사용하므로 관능특성 이 개선될 수 있을 것으로 생각되었다.

\section{저장성}

저온에서 보관, 유통되는 요구르트의 저장 기간 중 품질 안정 성을 확인하기 위하여 주박 당화물의 첨가하여 $40{ }^{\circ} \mathrm{C}$ 에서 12 시 간 발효시켜 제조한 요구르트를 $4{ }^{\circ} \mathrm{C}$ 에서 냉장 보관하면서 $\mathrm{pH}$, 적정산도, 젖산균 수의 변화를 경시적으로 조사하였다. 그 결과 (Table 2), 저장 16 일까지 대조구와 주박 당화물을 첨가한 요구 르트의 $\mathrm{pH}$ 와 적정산도의 변화는 미미하였다. 한편 젖산균 수는 대조군과 주박 당화물을 첨가한 실험군에서 모두 저장기간 동 안 약간 감소하여 저장 16 일까지 $10^{7} \mathrm{CFU} / \mathrm{g}$ 이상으로 유지되 었다. 저장기간 중 이러한 $\mathrm{pH}$, 적정산도 및 젖산균수의 변화는 변화는 탈지분유에 클로렐라 분말을 $0.2-1.0 \%$ 첨가하여 제조한 요구르트의 저장 중 변화[28]와 매우 유사한 경향이었다.

Table 1 Sensory evaluation results of yogurt added with enzymatically saccharified Korean rice wine lees powder after fermentation at $40{ }^{\circ} \mathrm{C}$ for $12 \mathrm{~h}$

\begin{tabular}{cccccc}
\hline \hline $\begin{array}{c}\text { Korean rice wine lees } \\
\text { hydrolysate }(\%)\end{array}$ & Color & Flavor & Taste & Viscosity & Overall acceptability \\
\hline 0 & $3.60 \pm 0.51^{\mathrm{a}}$ & $4.13 \pm 0.92^{\mathrm{a}}$ & $3.80 \pm 0.94^{\mathrm{a}}$ & $3.47 \pm 0.83^{\mathrm{a}}$ & $3.93 \pm 0.59^{\mathrm{a}}$ \\
0.5 & $3.73 \pm 0.88^{\mathrm{a}}$ & $3.80 \pm 0.80^{\mathrm{ab}}$ & $3.53 \pm 1.13^{\mathrm{ab}}$ & $3.13 \pm 0.92^{\mathrm{a}}$ & $3.40 \pm 0.83^{\mathrm{ab}}$ \\
1.0 & $3.07 \pm 0.70^{\mathrm{b}}$ & $3.40 \pm 1.12^{\mathrm{ab}}$ & $3.20 \pm 1.08^{\mathrm{ab}}$ & $2.93 \pm 1.03^{\mathrm{a}}$ & $3.20 \pm 1.01^{\mathrm{b}}$ \\
2.0 & $3.00 \pm 0.76^{\mathrm{b}}$ & $3.27 \pm 1.22^{\mathrm{b}}$ & $2.80 \pm 0.86^{\mathrm{b}}$ & $2.93 \pm 0.88^{\mathrm{a}}$ & $2.93 \pm 0.96^{\mathrm{b}}$ \\
\hline
\end{tabular}

${ }^{1}$ Data are means $\pm \mathrm{SD}(\mathrm{n}=20)$

${ }^{2}$ Different superscripts within column indicate significant difference $(p<0.05)$ 
Table 2 Changes in quality of yogurt prepared with different levels of enzymatically saccharified Korean rice wine lees powder during storage at $4{ }^{\circ} \mathrm{C}$

\begin{tabular}{|c|c|c|c|c|c|c|c|c|}
\hline & \multirow{2}{*}{$\begin{array}{c}\text { Korean rice wine lees } \\
\text { hydrolysate }(\%)\end{array}$} & \multicolumn{7}{|c|}{ Storage period (day) } \\
\hline & & 0 & 3 & 6 & 9 & 11 & 13 & 16 \\
\hline \multirow{4}{*}{$\mathrm{pH}$} & 0 & 4.43 & 4.44 & 4.49 & 4.44 & 4.49 & 4.43 & 4.39 \\
\hline & 0.5 & 4.33 & 4.33 & 4.39 & 4.33 & 4.40 & 4.33 & 4.31 \\
\hline & 1.0 & 4.24 & 4.25 & 4.30 & 4.24 & 4.32 & 4.25 & 4.21 \\
\hline & 2.0 & 4.19 & 4.20 & 4.24 & 4.20 & 4.26 & 4.19 & 4.15 \\
\hline \multirow{4}{*}{$\begin{array}{c}\text { Titratable acidity } \\
\qquad(\%)\end{array}$} & 0 & 0.74 & 0.73 & 0.78 & 0.81 & 0.78 & 0.83 & 0.81 \\
\hline & 0.5 & 0.85 & 0.76 & 0.76 & 0.86 & 0.83 & 0.89 & 0.89 \\
\hline & 1.0 & 0.90 & 0.83 & 0.87 & 0.92 & 0.91 & 0.95 & 0.97 \\
\hline & 2.0 & 1.01 & 0.90 & 0.94 & 1.00 & 1.00 & 1.05 & 1.08 \\
\hline \multirow{4}{*}{$\begin{array}{l}\text { Viable cell counts } \\
\qquad(\mathrm{CFU} / \mathrm{g})\end{array}$} & 0 & $5.33 \times 10^{8}$ & $2.50 \times 10^{8}$ & $5.10 \times 10^{7}$ & $4.47 \times 10^{7}$ & $2.10 \times 10^{8}$ & $1.47 \times 10^{8}$ & $5.73 \times 10^{7}$ \\
\hline & 0.5 & $2.93 \times 10^{8}$ & $5.00 \times 10^{8}$ & $5.60 \times 10^{8}$ & $2.06 \times 10^{8}$ & $3.60 \times 10^{8}$ & $2.04 \times 10^{7}$ & $1.23 \times 10^{7}$ \\
\hline & 1.0 & $5.83 \times 10^{8}$ & $3.80 \times 10^{8}$ & $9.20 \times 10^{7}$ & $2.26 \times 10^{8}$ & $3.87 \times 10^{8}$ & $1.83 \times 10^{8}$ & $7.23 \times 10^{7}$ \\
\hline & 2.0 & $4.53 \times 10^{8}$ & $3.23 \times 10^{8}$ & $1.08 \times 10^{8}$ & $1.97 \times 10^{8}$ & $6.90 \times 10^{7}$ & $6.90 \times 10^{7}$ & $3.53 \times 10^{7}$ \\
\hline
\end{tabular}

\section{초 록}

본 연구에서는 효소 처리한 주박 당화물 분말을 발효식품에 이 용하고자 상업용 Lactobacillus acidophilus, Streptococcus thermophilus, Bifidobacterium longum 혼합 균주를 이용하여 탈지분유에 주박 당화물을 첨가하여 요구르트를 제조하고 주박 당화물 분말의 첨가량에 따른 요구르트의 발효특성과 저장성을 조사하였다. 탈지분유에 주박 당화물을 $0.5-2.0 \%$ 첨가한 결과 적정산도는 주박 당화물의 사용량에 비례하여 증가하였으며, 12 시간 후 대조군 $0.72 \%$ 에서 주박 당화물 첨가 요구르트는 0.77 $0.90 \%$ 로 증가하였다. $\mathrm{pH}$ 의 변화도 적정산도의 변화와 일치하는 경향이었다. 젖산균 생균수는 주박 당화물의 첨가량에 비례하여 증가하였으며, 12 시간 배양 후 대조군은 $7.83 \log \mathrm{CFU} / \mathrm{g}$ 에서 주박 당화물 첨가군은 8.01-8.13 $\log \mathrm{CFU} / \mathrm{g}$ 까지 증가하였다. 또 한 주박 당화물은 주박과는 상이하게 커드의 안정성에 대한 효 과가 매우 미미하였다. 관능평가 결과. 주박 당화물의 첨가 수 준은 $0.5 \%$ 가 적절하였다. 주박 당화물을 첨가한 요구르트를 $4{ }^{\circ} \mathrm{C}$ 에서 16 일간 저장하는 동안 $\mathrm{pH}$ 와 적정산도의 변화는 미미 하였고, 젖산균 수는 약간 감소하였으나 모든 조건에서 $10^{7}$ $\mathrm{CFU} / \mathrm{g}$ 이상으로 유지되었다.

\section{Keywords 발효특성 - 요구르트 - 저장성 - 주박 당화물}

감사의 글 본 연구는 2018 년도 청 운대학교 학술연구조성비의 지원을 받아 수행하였습니다.

\section{References}

1. Kim MS, Shin WC, Sohn HY (2015) Application of the lees of domestic traditional wine and its useful biological activity. J Life Sci 25: 1072 1079

2. Shon SK, Rho TH, Kim HJ, Bae SM (1990) Takju brewing of uncooked rice starch using Rhizopus koji. Korean J Appl Microbiol Biotechnol 18: 506-510

3. Kim SM, Cho Wk (2006) Effects of Takju (Korean turbid rice wine) lees on the serum glucose levels in streptozotocin-induced diabetic rats.
Korean J Food Culture 21: 638-643

4. Kim TY, Jeon TW, Yeo SH, Kim SB, Kim JS, Kwak JS (2010) Antimicrobial, antioxidant and SOD-like activity effect of Jubak extracts. Korean J Food \& Nutr 23: 299-305

5. Kang YJ, Park SJ, Bae K, Yoo JM, Pyo HB, Choi JH, Kim TJ (2011) Ethyl acetate extract of Korean rice wine lees inhibits IgE-mediated degranulation in rat basophilic leukemia RBL-2H3 cells and passive cutaneous anaphylaxis in mice. J Life Sci 21: 1364-1369

6. Kwon SC, Jeon TW, Park JS, Kwak JS, Kim TY (2012) Inhibitory effect of tyrosinase, ACE and xanthine oxidase, and nitrite scavenging activities of Jubark (alcohol filter cake) extracts. J Korean Soc Food Sci Nutr 41: 1191-1196

7. Park MJ, Kang HT, Kim MS, Shin WC, Sohn HY, Kim JS (2014) Antiinflammatory effects of extracts and their solvent fractions of rice wine lees. J Life Sci 24: 843-850

8. Park WY, Sung NY, Byun EH, Oh KH, Byun MW, Yoo YC (2015) Immuno-modulatory activities of polysaccharides separated from Jubak in microphage cells. J Korean Soc Food Sci Nutr 44: 1079-1083

9. Lee, HS, Kim SM (2010) Quality characteristics of morning rolls added with Makgeolli lees extract powder. Korean J Food Culture 25: 633-638

10. Jung HN, Kim HO, Shim HH, Jung HS, Choi OJ (2012) Quality characteristics of low-salt yacon Jangachi using rice wine lees during storage. J Korean Soc Food Sci Nutr 41: 383-389

11. Cho YH, Cho JS, Kim JY, Kim US, Choi JH, Park JH (2013) Quality characteristics of Sulgidduk with Makgeolli lees. J East Asian Soc Dietary Life 23: 227-233

12. Ko YS, Sim KH (2014) Quality characteristics and antioxidant activity of Jeung-pyun added with Ju-bak powder. J East Asian Soc Dietary Life 24: 190-200

13. Choi YS, Kim HW, Hwang KE, Song DH, Choi JH, Lee MA, Chung HJ, Kim CJ (2014) Physicochemical properties and sensory characteristics of reduced-fat frankfurters with pork back fat replaced by dietary fiber extracted from makgeolle lees. Meat Sci 96: 892-900

14. Yun CS, Kim HA, Kim YS (2015) Quality characteristics of muffin added with Makgeolli lees. Korean J Culinary Res 21: 198-211

15. Im CY, Kim MH, Kang WW (2017) Quality characteristics of cookies added with Takju pomace powder. Korean J Food Preserv 24: 8-12

16. Lim YS, Bae SM, Kim K (2004) Production of yeast spores from rice wine cake. Korean J Microbiol Biotechnol 32: 184-189

17. Kim WS (2011) Utilization of Makgeolli sludge for growth of probiotic bacteria. CNU J Agric Sci 38: 473-477

18. Ko YJ, Ryu CH (2016) Optimum fermentation condition of apple vinegar added with Korean rice wine lees extracts. J Agric Life Sci 50: 193-200 
19. Kim DC, In MJ (2016) Preparation and characteristics of yogurt added with Korean rice wine lees powder. J Appl Biol Chem 59: 345-349

20. In MJ, Choi SY, Kim HR, Park DB, Oh NS, Kim DC (2009) Acid production and phytate degradation using Leuconostoc mesenteroides KC51 strain in saccharified-rice suspension. J Appl Biol Chem 52: 33 37

21. Jeong EJ, Bang BH (2003) The effect on the quality of yogurt added water extracted from sea tangle. Korean J Food \& Nutr 16: 66-71

22. Paik SH, Bae HC, Nam MS (2004) Fermentation properties of yogurt added with rice. J Anim Sci \& Technol 46: 667-676

23. Chamber JV (1979) Culture and processing techniques important to the manufacture of good quality yogurt. Cult Dairy Prod J 14: 28-34

24. Kim KH, Ko YT (1993) The preparation of yogurt from milk and cereals. Korean J Food Sci Technol 25: 130-135

25. Sung JM, Choi HY (2014) Effect of mulberry powder on antioxidant activities and quality characteristics of yogurt. J Korean Soc Food Sci Nutr 43: 690-697

26. Vliet TV, Lakemond CMM, Visschers RW (2004) Rheology and structure of milk protein gels. Curr Opin Colloid Interface Sci 9: 298304

27. Kim DC, Won SI, In MJ (2015) Substitution effect of enzymatically hydrolyzed purple sweet potato powder on skim milk in yogurt preparation. J Appl Biol Chem 58: 311-316

28. Sung YM, Cho JR, Oh NS, Kim DC, In MJ (2005) Preparation and quality characteristics of curd yogurt added with chlorella. J Korean Soc Appl Biol Chem 48: 60-64 